\title{
Regulation of T cell immunity by cellular metabolism
}

\author{
Zhilin Hu, Qiang Zou (凶) , Bing Su (凶) \\ Shanghai Institute of Immunology, Department of Immunology and Microbiology, Key Laboratory of Cell Differentiation and Apoptosis of \\ Chinese Ministry of Education, Shanghai Jiao Tong University School of Medicine, Shanghai 200025, China
}

(C) The Author(s) 2018. This article is published with open access at link.springer.com and journal.hep.com.cn 2018

\begin{abstract}
T$ cells are an important adaptive immune response arm that mediates cell-mediated immunity. T cell metabolism plays a central role in $T$ cell activation, proliferation, differentiation, and effector function. Specific metabolic programs are tightly controlled to mediate $T$ cell immune responses, and alterations in $T$ cell metabolism may result in many immunological disorders. In this review, we will summarize the main $T$ cell metabolic pathways and the important factors participating in $T$ cell metabolic programming during $T$ cell homeostasis, differentiation, and function.
\end{abstract}

Keywords T cell immunity; metabolic pathways; nutrient uptake; metabolic checkpoints

\section{Introduction}

Different types of immune cells play specialized roles in host defense against tumor cells or pathogens [1,2]. These diverse types of immune cells are stimulated by all kinds of threats and activated by extracellular and intracellular cues to exert their function through diverse, as well as complicated, signaling cascades. Different stimuli also mediate the migration of immune cells to different cell microenvironments and initiate their proliferation and differentiation. In the processes of leukocyte immunity, immune cells depend on nutrients and metabolites to facilitate and enhance their functions to meet the energy and biosynthesis demands $[3,4]$. Therefore, the metabolic characteristics of immune cells are crucial for their diverse functions.

$\mathrm{T}$ cell lineage is an important immune cell population, which is an essential component of the adaptive immune system. The ligation of the $\mathrm{T}$ cell receptor (TCR) by antigen/MHC complexes and the interaction of costimulation receptors regulate $\mathrm{T}$ cell activation. After stimulation, naïve $\mathrm{T}$ cells begin to proliferate and differentiate into highly specific effector $\mathrm{T}$ cells (Teff), such as Th1, Th2, Th17, T follicular helper (Tfh) cells, regulatory $\mathrm{T}$ cells (Treg), and cytotoxic $\mathrm{CD} 8^{+} \mathrm{T}$ lympho-

Received April 6, 2018; accepted July 17, 2018

Correspondence: Bing Su, bingsu@sjtu.edu.cn; Qiang Zou, Qzou1984@sjtu.edu.cn cytes [5-7]. Diverse $T$ cell subsets serve different but specific functions in response to a wide variety of stimuli. Indeed, T lymphocyte and other lymphocyte subsets share several common characteristics, such as the capability to sense and respond to extracellular and intracellular dangerous signals. When the $\mathrm{T}$ cells differentiate from the naïve $T$ cells into different subsets of $T$ cells, stringent metabolic regulation is required. Indeed, specific metabolic pathways are critically associated with T cell homeostasis, differentiation, and function. In this review, we provide a general overview of the metabolic regulation of $\mathrm{T}$ cell immunity.

\section{Metabolism of different $\mathrm{T}$ cell subsets}

Without antigen stimulation, naïve $T$ cells are relatively quiescent. The energy metabolic demands of naïve $T$ cells mainly come from oxidative phosphorylation (OXPHOS). Upon TCR stimulation, naïve T cells increase glycolytic metabolism to differentiate into activated $\mathrm{T}$ cells and enter secondary lymphoid organs or tissues. During $\mathrm{T}$ cell activation, proliferation, and differentiation, energy metabolism mainly depends on aerobic glycolysis and OXPHOS. Notably, glycolytic metabolism can distinguish Th1, Th2, and Th17 effector cells from Treg. When the antigenic stimulus decreases or disappears, most of the Teff cells undergo apoptosis [8] and a small number of Teff cells are converted into memory $\mathrm{T}$ cells (Tmem) $[9,10]$. The development of Treg and Tmem mainly depends on fatty acid oxidation (FAO) and catabolism. Tmem reenter 
the resting state, and their energy metabolism depends on OXPHOS (Fig. 1).

Recent reports have indicated that the metabolic regulation of Tfh cells is different from that of Th1 cells upon viral infection [11,12]. The metabolic demands of Tfh cells come from mitochondrial metabolism, and the metabolic activity of LCMV-specific Tfh cells is less than that of Th1 cells. Lower levels of AKT and mammalian target of rapamycin (mTOR) signaling were observed in Tfh cells than in Th1 cells, thereby inhibiting glycolysis and promoting Tfh cell differentiation. Bcl6 is essential for Tfh cell differentiation $[13,14]$ and inhibits IL-2-mediated glycolysis pathways in Thl cells [15], indicating that Bcl6 and its regulatory proteins may suppress the glycolysis pathway in Tfh cells. Other reports indicate that IL-2 signaling can differentially regulate the binding of the transcription factor FOXO1/3a to the Bcl6 locus [16],

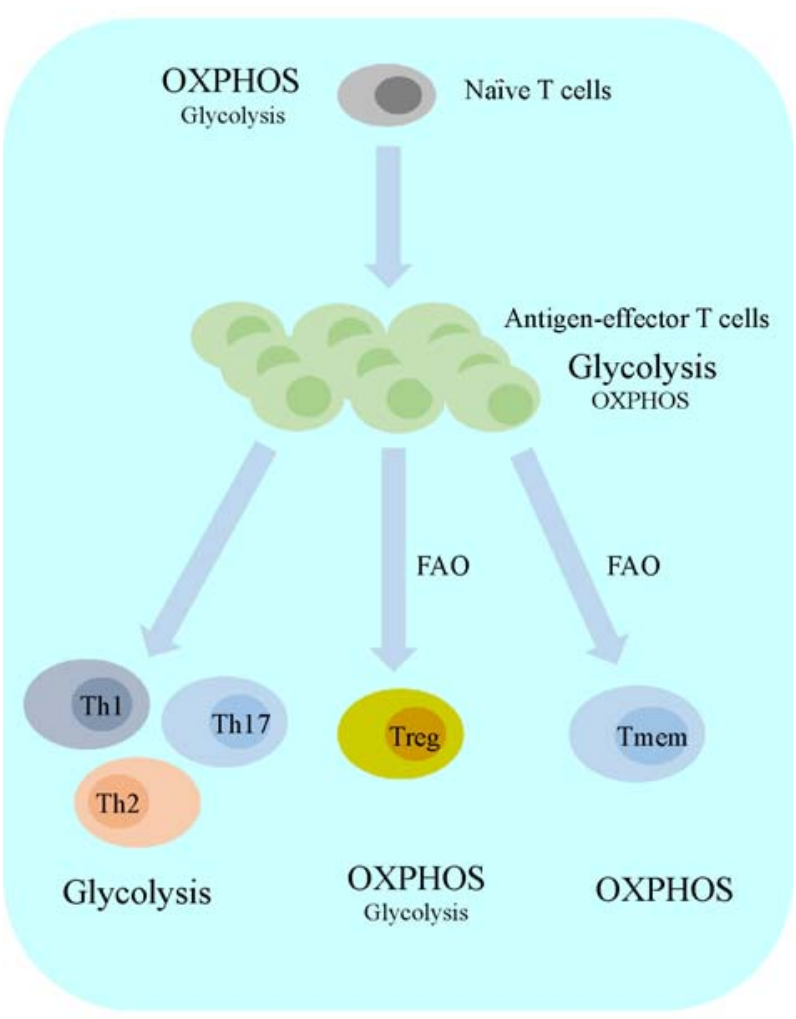

Fig. 1 Metabolic regulation of the T cell life cycle. The energy demands of naïve $\mathrm{T}$ cells mainly come from oxidative phosphorylation (OXPHOS). After $\mathrm{T}$ cell receptor (TCR) stimulation, the naïve $T$ cells differentiate into antigen-effector $\mathrm{T}$ cells, whose energy metabolism mainly depends on aerobic glycolysis and OXPHOS. Glycolytic metabolism distinguishes CD4 Th1, Th2, and Th17 effector cells from regulatory T cells (Treg). The development of Treg and memory T cells (Tmem) mainly depends on fatty acid oxidation (FAO) and catabolism. Membrane $\mathrm{T}$ cells reenter the resting state, and their energy metabolism depends on OXPHOS. indicating that IL-2 is likely to regulate the $\mathrm{FOXO} / \mathrm{Bcl} 6$ axis to mediate $\mathrm{Tfh}$ cell glycolysis and differentiation.

In the case of persistent antigenic stimuli, such as cancer and chronic infection, Teff cells gradually lose their function, resulting in $\mathrm{T}$ cell exhaustion. Until now, how different cellular metabolic pathways participate in the $\mathrm{T}$ cell exhaustion process is not yet clear. In tumor models, tumor-infiltrating $\mathrm{T}$ lymphocytes have a phenotype of reduced mitochondrial mass and OXPHOS [17]. In early chronic LCMV infection, the expression of genes involved in OXPHOS, citric acid cycling, and fatty and amino acid metabolism increased in exhausted T cells [18]. Although mitochondrial respiration is decreased in early exhausted $\mathrm{T}$ cells, the mitochondrial mass was greater in early exhausted T cells than that in Teff cells. Moreover, early exhausted $\mathrm{T}$ cells showed depolarization of the mitochondrial membrane with a reduced OXPHOS phenotype. Studies have shown that the transcriptional regulatory factor PPAR- $\gamma$ coactivator 1a (PGC-1a) is a potential regulatory target for metabolic dysfunction in exhausted $\mathrm{T}$ cells. Earlier studies have shown that PGC-1a is involved in mitochondrial biosynthesis [19], and the overexpression of PGC-1a can maintain Teff cell function in tumor models and in chronic infections [17,18]. In a mouse model of B cell leukemia, mTORC1 activity and the expression level of the glucose transporter Glut1 are decreased in exhausted $T$ cells, resulting in decreased glucose uptake and reduced level of glycolytic enzyme hexokinase [20]. Thus, T cell exhaustion is accompanied by impaired T cell metabolism. Whether the impaired metabolism is the cause or consequence, or only a correlation, of $\mathrm{T}$ cell exhaustion requires further investigation.

\section{Key metabolic pathways of T cell immunity}

\section{Glycolysis and tricarboxylic acid cycle}

During the activation of $\mathrm{T}$ cells, the production of ATP mainly comes from the catabolism of glucose and fatty acids. Upon entering the cell, glucose is rapidly phosphorylated by hexokinase, producing glucose 6-phosphate and consuming a molecule of ATP. The glycolysis process can generate high-energy molecules, such as nicotinamide adenine dinucleotide (NADH) and ATP, and form two molecules of pyruvate. Intermediates produced during glycolysis are transferred to the pentose phosphate pathway, serine biosynthetic pathway, $\beta$-oxidation pathway, or glycogenesis pathway, resulting in nucleotides, fatty acids, and glycogen generation, which are needed for $\mathrm{T}$ cell metabolism. After pyruvate is synthesized, it is delivered to the mitochondria and undergoes further breakdown through the tricarboxylic acid (TCA) cycle. Inside the mitochondrial matrix, pyruvate is carboxylated to produce oxaloacetate or decarboxylated and combined with 
coenzyme A (CoA) to form acetyl-CoA. Then, under the function of citric acid synthase, oxaloacetate combines with acetyl-CoA to produce citrate. During the TCA cycle, oxaloacetate is regenerated and recombined with a new molecule of acetyl-CoA. This cycle produces two reducing agents, namely, NADH and flavin adenine dinucleotide (FADH2), which donate electrons to the cytochrome of the electron transport chain, resulting in large amounts of ATP by OXPHOS, participating in $\mathrm{T}$ cell metabolic regulation. By contrast, without mitochondrial involvement, pyruvate can be catalyzed by lactate dehydrogenase to generate lactate. Lactate generation is involved in energy metabolism.

\section{Aerobic glycolysis}

Even in the presence of abundant oxygen, $\mathrm{T}$ cells can preferentially use glycolysis to produce ATP. The energy and metabolites produced by aerobic glycolysis can support $\mathrm{T}$ cell activation and rapid proliferation [21,22]. The energy of many activated $\mathrm{T}$ lymphocytes comes primarily from aerobic glycolysis, such as Teff cells (Th1, $\mathrm{Th} 2$, and Th17 $\mathrm{CD} 4^{+}$subsets and cytotoxic $\mathrm{CD} 8^{+} \mathrm{T}$ cells). In this condition, the majority of pyruvate is rapidly converted into lactate and expelled. In CD4 ${ }^{+}$Teff cells, a part of the pyruvate produced during aerobic glycolysis remains to be metabolized via TCA and OXPHOS. Notably, $\mathrm{CD}^{+} \mathrm{T}$ cells do not boost OXPHOS upon activation [23-25].

\section{Fatty acid oxidation}

$\mathrm{T}$ cell growth and organelle biosynthesis are mainly dependent on fatty acid metabolism [26]. Treg and Tmem support their function and survival mainly through lipid metabolism mediated by FAO [25,27]. Excess exogenous fatty acids exhibit a dominant negative effect on the acquisition of the Th17 phenotype. Treg is crucial for maintaining immune homeostasis. Forced reliance on FAO during in vitro $\mathrm{T}$ cell differentiation favors Treg generation [27]. The inhibition of the key metabolic regulator, mTOR, during $\mathrm{CD}^{+}{ }^{+} \mathrm{T}$ cell activation enhances $\mathrm{FAO}$ and reduces aerobic glycolysis favor Treg production [28]. Metabolic regulation is involved in the rapid reactivation of Tmem cells. Within the $\mathrm{CD}^{+}$memory lineage, the production and persistence of Tmem, as well as repeat-antigen-induced reactivation, has been reported to be dependent on FAO regulation [25,29]. Tmem cells have a greater mitochondrial mass than other T cell subsets, specifically expressing the FAO-related enzymes and the carnitine palmitoyl transferase system proteins [29-31], resulting in a stronger spare respiratory capacity (SRC). SRC represents the capability of cells to generate energy in response to activation or stress signals $[29,32]$. Thus, the stronger SRC capacity of the Tmem cell promotes their survival under harsh conditions [33].

\section{Nutrient uptake and T cell immunity}

Following TCR ligation and co-stimulatory factor activation, T cells show a rapid proliferation and reprogramming, resulting in the high expression of cytotoxins, cell surface molecules, and cytokines. The growth, proliferation, and differentiation of $\mathrm{T}$ cells, as well as related protein synthesis, are accompanied by metabolite uptake that provides the energy required for T cell metabolism [34,35]. T cell activation relies on nutrient uptake; thus, glucose and amino acid are crucial for $T$ cell growth and activation [36].

\section{Glucose uptake}

In mammals, glucose uptake depends on the expression of the cell surface glucose transporter family (Glutl-14) [3739]. Glucose transporters are selectively expressed on the $\mathrm{T}$ cell surface, including Glut1, 2, 3, 6 and 8, of which Glut1 is the most important glucose transporter responsible for basal glucose transport in all immune cells [40]. During the activation process, $\mathrm{T}$ cells need to uptake nutrients to promote their proliferation and differentiation and to meet the metabolic needs of the effector molecules. For the Teff subset, glucose uptake is crucial for activation-associated functions [40]. The activation of costimulatory signals promotes PI3K/Akt signaling to upregulate Glut1 [41]. A high expression of Glut1 alone on the cell surface is sufficient to promote a dramatic increase in glucose influx, which meets the rapidly increasing cell demands for glycolysis $[42,43]$. The overexpression of Glut1 enhances naïve $\mathrm{T}$ cell proliferation and activation [44]. Conversely, the deletion of Glut1 inhibits the proliferation and differentiation of murine Teff subsets when activated in vivo [40].

\section{Amino acid uptake}

T cell activation also depends on amino acid uptake, and the high expression of amino acid transporter proteins increases the activation of $T$ cells. During the $T$ cell activation process, glutamine is the most important amino acid. Glutaminolysis is required to absorb and break down glutamine, and its derivatives can be fed into the TCA cycle for the de novo synthesis of lipid and NADPH, which benefits T cell activation. Several specific transporters play an important role in glutamine uptake. The antiporter, ASC amino acid transporter 2 (ASCT2; also known as Slcla5), is upregulated during TCR activation [45]. In the mouse EAE model, $\mathrm{CD}^{+}{ }^{+}$T-cell-specific deletion of ASCT2 significantly suppresses the immune response of Th1 and Th17 
and alleviates the progress of EAE in mice [45]. $\mathrm{CD}^{+} \mathrm{T}$ cell function depends primarily on the leucine transport pathway. Following exposure to activating signals through TCR ligation and co-stimulation, system L neutral amino acid transporter 1 (LAT1; also referred to as Slc7a5) is upregulated in the $\mathrm{CD}^{+}$and $\mathrm{CD} 8^{+} \mathrm{T}$ cell surface. LAT1 is primarily responsible for the absorption of important branched chain (e.g., leucine and isoleucine) and aromatic (e.g., tryptophan and phenylalanine) amino acids. LAT1 also participates in a small amount of glutamine transport [46-48]. $\mathrm{CD}^{+} \mathrm{T}$ cell differentiation and migration are dependent on LAT1-mediated leucine influx [49-51]. Therefore, LAT1 deficiency impairs T cell proliferation and effector differentiation. Taken together, an appropriate intracellular concentration of amino acids is critical to establish an effective immune response during $\mathrm{T}$ cell activation.

\section{Key metabolic checkpoints of T cell immunity}

\section{Mammalian target of rapamycin}

mTOR is a serine/threonine kinase discovered as the cellular target of rapamycin [52], which exists in the form of two complexes, namely, mTORC1 and mTORC2. The activity of mTORC1 and mTORC2 significantly affects $\mathrm{CD}^{+} \mathrm{T}$ cell differentiation. Treatment with rapamycin inhibits Teff cell differentiation by primarily affecting the mTORC 1 activity [53-55]. Inhibition of the mTORC 1 and mTORC2 activities by deleting mTOR affects the differentiation of Th1, Th2, and Th17 [53]. However, specific knockout of Rheb in $\mathrm{T}$ cells, which inhibits mTORC1 activity alone, impairs Th1 and Th17 cell differentiation but does not affect $\mathrm{Th} 2$ cell differentiation [28]. Several studies further indicated that Th17 differentiation is inhibited in the T-cell-specific deletion of Raptor mice, whereas Th1 differentiation is unaffected [56]. mTORC1 reportedly promotes the expression of S6K2, thus affecting the differentiation of Th17. mTORC1 also promotes the nucleus translocation ROR $\gamma \mathrm{t}$, a major transcription factor of Th17 [56]. Treatment with arctigenin, a chemical inhibitor of mTORC1, inhibits the Th1 and Th17 differentiation [57]. Using a T-cell-specific deletion of the Raptor model, another group observed that the loss of mTORC1 restricts Th2 differentiation [58]. Notably, the role of mTORC2 in Teff cell differentiation is complicated. Although most studies showed that deletion of Rictor in T cells suppresses Th2 differentiation [28,59], mTORC2 has also been shown to promote Th1 differentiation [59]. In the case of T-cell-specific deletion of Sin1, another key component of mTORC2, no obvious preference for Th1, Th2, and Th17 cell differentiation in vitro was observed, indicating that the role of $\mathrm{mTORC} 2$ in
$\mathrm{T}$ helper cell differentiation and effector function is more complex than previously thought (Ouyang, Omotooke, \& $\mathrm{Su}$, unpublished data).

mTOR signaling plays an important role in the metabolic regulation of $\mathrm{T}$ cells. In view of glycolysis, mTORC1 promotes Glut1 gene expression and in turn enhances glycolysis [60]. Glutamine uptake is significantly increased in the early stages of Th17 differentiation [61], and the activation of mTORC1 in $\mathrm{CD}^{+} \mathrm{T}$ cells is dependent on ASCT2. By contrast, Th17 differentiation is impaired in ASCT2-deficient mice, illustrating that glutamine regulated Th17 differentiation [45]. Notably, mTOR induces Th17 differentiation by promoting the expression of hypoxia-inducible factor $1 \alpha$ (HIF $1 \alpha)$. mTOR and HIF $1 \alpha$ promote glucose uptake and glycolysis at the transcriptional and translational levels [62]. Previous studies have shown that Th17 cells are more dependent on glycolysis than any other subset of T cells $[28,56,63]$. Without HIF $1 \alpha$, Th17 development in mice is significantly impaired [58]. HIF1 $\alpha$ can enhance glucose uptake and promote glycolysis by upregulating the expression of Glut1 and pyruvate dehydrogenase kinase 1 (PDK1). Glut1 promotes glucose transport across the cell membrane, and PDK1 prevents pyruvate from entering the TCA cycle, driving it to lactate, and promoting glycolysis. The activation of mTOR signaling promotes fatty acid synthesis (FAS) and aerobic glycolysis, thereby further inhibiting Treg differentiation. In the absence of mTORC1 and mTORC2 activities, naïve $\mathrm{CD}^{+}{ }^{+} \mathrm{T}$ cells only differentiate into Treg $[28,56]$. Several studies have shown that a certain connection exists between the proliferation of Treg and the transient inhibition of mTOR signaling. However, thus far, the underlying mechanism of these phenomena is still unclear $[28,64]$.

\section{AMP-activated protein kinase}

AMP-activated protein kinase (AMPK) is an enzyme that responds to the harsh survival environment of the cells and is activated in the absence of energy or other physiological stresses. Therefore, AMPK is an important cellular sensor of energy stress. The activation of AMPK results in the downregulation of energy-consuming metabolism, such as fatty acid or protein synthesis, and the upregulation of catabolic metabolism, such as glucose and FAO $[65,66]$. AMPK activation regulates many of the important enzymes involved in the metabolic pathways of FAO and FAS, such as ACC1, ACC2, CPTI, and SREBP-1c. CPT1, as the rate-limiting enzyme in FAO, is critical for the metabolism of FAO. The phosphorylation of ACC $1 / 2$ and SREBP-1c inhibits FAS but activates FAO [90].

AMPK activation inhibits anabolic metabolism, and AMPK can inhibit glycolysis $[65,67,68]$. AMPK activation also inhibits $\mathrm{T}$ cell differentiation. As mentioned previously, Th17 cells are more dependent on glycolysis 
and Treg cells are more dependent on FAO, such that the capability of AMPK-mediated metabolism regulates the balance between Th17 and Treg. AMPK activation can drive naïve $\mathrm{T}$ cells to differentiate into Treg in vitro and in vivo. By contrast, the loss of AMPK results in upregulated mTOR activity and increased glycolysis [67]. Studies have shown that metformin, an activator of AMPK, can inhibit
Th1 and Th17 differentiation [69,70]. Treatment with metformin or AICAR, a direct activator of AMPK, alleviates the progress in some inflammatory mouse models [71-75]. Notably, metformin treatment increases the population of Treg in an asthmatic mouse model, further indicating that AMPK activation mediates FAO upregulation [27] (Fig. 2).

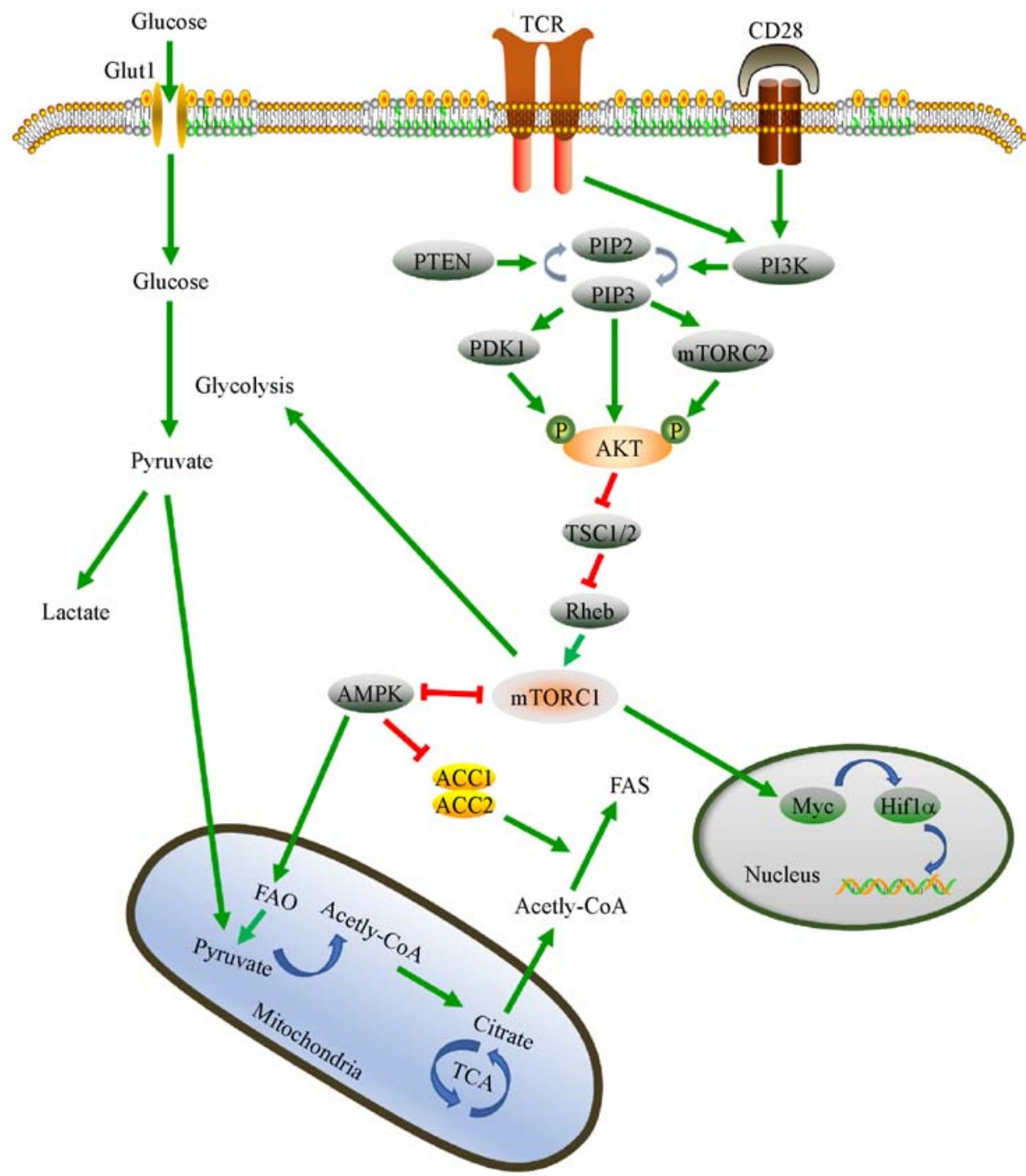

Fig. 2 Simplified scheme of T cell metabolism regulated by mTOR signaling. TCR and CD28 signals induce the expression of metabolism-related genes, such as glucose transporter Glut1 (murine gene name Slc2a1), and increase the glucose uptake of T cells. Then, glucose is degraded by glycolysis to generate pyruvate molecules, lactate, or acetyl-CoA. Acetyl-CoA is required for the tricarboxylic acid (TCA) cycle and utilized as a precursor of fatty acid synthesis (FAS). TCR and CD28 stimulation also induces AKT phosphorylation via PDK1 and $\mathrm{mTORC} 2$ and promotes mTORC1 activation, leading to the elevated glycolysis and increased levels of pyruvate molecules. By contrast, AMPK promotes FAO and inhibits FAS by negatively regulating ACC1/2. AMPK can inhibit mTOR activity to downregulate glycolysis. Therefore, mTOR and AMPK act as negative regulators for each other. 


\section{Cellular Myc (c-Myc)}

c-Myc is discovered as a driving transformative factor for lymphoma, which is caused by dysregulated $M y c$ gene expression [76,77]. c-Myc is rapidly upregulated in the early TCR and co-stimulatory molecule-triggered signaling cascade. In the in vivo models, systemic knockout of cMyc is lethal, but in vitro c-Myc deficiency can significantly inhibit glycolysis metabolism. Lack of cMyc downregulates the expression of enzymes involved in the pentose phosphate pathway. Notably, specific deletion of c-Myc in T cells reduces the expression of LAT1 and ASCT2 $[45,78]$ and inhibits T cell uptake of amino acids. c-Myc promotes $\mathrm{T}$ cell activation mainly by upregulating the transporters of glucose and amino acid, as well as promoting glycolysis and glutaminolysis [78,79]. Instability of c-Myc expression leads to the downregulation of Glut1, which reduces glutamine and arginine uptake of $\mathrm{T}$ cells and inhibits glutamine glutaminolysis and $\mathrm{T}$ cell glycolysis [79]. These findings indicate that c-Myc plays a multifaceted role in T cell activation and T cell metabolism.

\section{Tumor microenvironment and $\mathrm{T}$ cell metabolism}

Immunometabolism plays a key role in adaptive immunity and is particularly important for effective antitumor T cell responses. In the tumor microenvironment, $\mathrm{T}$ cells are affected by the inhibitory network [80] and $\mathrm{T}$ cell metabolism is altered [81], which promotes tumor escape and development $[82,83]$. Recent studies have shown that antitumor functions of effector $\mathrm{T}$ cells are impaired in the tumor microenvironment [84]. In fact, the tumor microenvironment forms a complex immunosuppression network that inhibits metabolic regulation during tumor development [85], thereby limiting $\mathrm{T}$ cell activation and inducing $\mathrm{T}$ cell anergy $[86,87]$. However, the exact mechanism is still unclear. A previous study reported that changes in $\mathrm{T}$ cell metabolic regulation inhibit the antitumor capability of $\mathrm{T}$ cells, leading to tumor escape [88]. In the tumor microenvironment, metabolic interference and nutrients competition exist between cancer and $\mathrm{T}$ cells, which are important to drive cancer development $[89,90]$. Tumor cells require a large amount of energy metabolism to proliferate by increasing glycolysis and glucose uptake from the surrounding environment [91]. Therefore, the abnormal metabolism of tumor cells inhibits the immune metabolism of $\mathrm{T}$ cells, weakens the $\mathrm{T}$ cells glycolytic pathway, and reduces the capability of $\mathrm{T}$ cells to secrete cytokines, resulting in the conversion of effector $\mathrm{T}$ cells into ineffective cells [92].

Studies have shown that Treg differentiation is inconducive to tumor immunity $[93,94]$. In contrast to effector T cells, Treg are more likely to be activated in the tumor microenvironment [95]. When the AMPK signaling pathway inhibits the mTOR signaling pathway, the balance between Teff and Treg may be directly disturbed in the tumor microenvironment $[96,97]$. In contrast to mTOR cascade, AMPK cascade is dominantly activated when nutrients are absent and oxidative metabolism is enhanced [97]. Notably, AMPK can be mediated by hyperphosphorylation and thus activated in Treg. Therefore, Treg function is enhanced to impair effector $T$ cell functions in the tumor microenvironment, which in turn facilitates tumor development.

\section{Conclusions}

Immune cells play an important role in maintaining homeostasis and regulating cellular functions. T lymphocytes act as an important immune cell population involved in immunoregulation. Recently, many studies have shown that metabolism and $\mathrm{T}$ cell immunity are closely related. Metabolites are utilized to provide energy during $\mathrm{T}$ cell activation, and glycolysis and FAO are important cellular metabolic pathways involved in this process. Intermediates produced by cell metabolism and glucose and amino acid intake promote $\mathrm{T}$ cell activation, and the expression of glucose and amino acid transporters on the cell surface benefits $T$ cell activation.

During activation, $\mathrm{T}$ cells differentiate into diverse effector molecules and $\mathrm{T}$ cell subsets, which possess specialized function, resulting in dynamic T cell immunity. Metabolic pathways involved in mediating $\mathrm{T}$ cell function within diverse $T$ cell subsets are different, and specific nutrient uptake is different in these subsets.

Numerous studies have shown that the regulation of $T$ cell immunity effectively controls the occurrence of immune diseases and maintains $\mathrm{T}$ cell homeostasis. Metabolic regulation is important for $\mathrm{T}$ cell function, which is crucial for immune disease therapy. Although a large number of studies have reported the relationship between metabolic regulation and immune diseases, thus far, how to control cell metabolism effectively to provide precise immunotherapy still requires extensive research.

\section{Acknowledgements}

This work was supported by grants from the National Natural Science Foundation of China (Nos. 81430033, 31470845, and 31670896), the Recruitment Program of Global Experts of China, Shanghai Rising-Star Program (No. 16QA1403300), Shanghai Science and Technology Committee (No. 16410723300), Shanghai Municipal Commission of Health and Family Planning (Nos. 20174Y0049, 20174Y0191, and 15GWZK0102), Shanghai Jiao Tong University "Program for young teachers" (No. KJ30214170006) and "Medical and Engineering Cross Research Foundation" (No. YG2016QN77). 


\section{Compliance with ethics guidelines}

Zhilin Hu, Qiang Zou, and Bing Su declare no conflict of interest. This manuscript is a review article and does not involve a research protocol requiring approval by the relevant institutional review board or ethics committee.

Open Access This article is distributed under the terms of the Creative Commons Attribution 4.0 International License (http:// creativecommons.org/licenses/by/4.0/), which permits unrestricted use, distribution, and reproduction in any medium, provided the appropriate credit is given to the original author(s) and the source, and a link is provided to the Creative Commons license, which indicates if changes are made.

\section{References}

1. Segal BH. Role of macrophages in host defense against aspergillosis and strategies for immune augmentation. Oncologist 2007; 12 (Suppl 2): 7-13

2. Harwood CG, Rao RP. Host pathogen relations: exploring animal models for fungal pathogens. Pathogens 2014; 3(3): 549-562

3. Ron-Harel N, Sharpe AH, Haigis MC. Mitochondrial metabolism in T cell activation and senescence: a mini-review. Gerontology 2015; 61(2): 131-138

4. Pearce EL, Pearce EJ. Metabolic pathways in immune cell activation and quiescence. Immunity 2013; 38(4): 633-643

5. Pennock ND, White JT, Cross EW, Cheney EE, Tamburini BA, Kedl RM. T cell responses: naïve to memory and everything in between. Adv Physiol Educ 2013; 37(4): 273-283

6. Lauvau G, Soudja SM. Mechanisms of Memory T Cell Activation and Effective Immunity. Crossroads, between Innate and Adaptive Immunity. Part of the Advances in Experimental Medicine and Biology book series (AEMB, volume 850). 2015; 850: 73-80

7. Brenchley JM, Douek DC, Ambrozak DR, Chatterji M, Betts MR, Davis LS, Koup RA. Expansion of activated human naïve T-cells precedes effector function. Clin Exp Immunol 2002; 130(3): 432440

8. Zhang N, Hartig H, Dzhagalov I, Draper D, He YW. The role of apoptosis in the development and function of $\mathrm{T}$ lymphocytes. Cell Res 2005; 15(10): 749-769

9. Schumacher TN, Gerlach C, van Heijst JW. Mapping the life histories of T cells. Nat Rev Immunol 2010; 10(9): 621-631

10. Wang R, Green DR. Metabolic checkpoints in activated T cells. Nat Immunol 2012; 13(10): 907-915

11. Ray JP, Staron MM, Shyer JA, Ho PC, Marshall HD, Gray SM, Laidlaw BJ, Araki K, Ahmed R, Kaech SM, Craft J. The interleukin2-mTORc1 kinase axis defines the signaling, differentiation, and metabolism of T helper 1 and follicular B helper T cells. Immunity 2015; 43(4): 690-702

12. Wu T, Shin HM, Moseman EA, Ji Y, Huang B, Harly C, Sen JM, Berg LJ, Gattinoni L, McGavern DB, Schwartzberg PL. TCF1 is required for the $\mathrm{T}$ follicular helper cell response to viral infection. Cell Reports 2015; 12(12): 2099-2110

13. Johnston RJ, Poholek AC, DiToro D, Yusuf I, Eto D, Barnett B,
Dent AL, Craft J, Crotty S. Bcl6 and Blimp-1 are reciprocal and antagonistic regulators of $\mathrm{T}$ follicular helper cell differentiation. Science 2009; 325(5943): 1006-1010

14. Nurieva RI, Chung Y, Martinez GJ, Yang XO, Tanaka S, Matskevitch TD, Wang YH, Dong C. Bcl6 mediates the development of T follicular helper cells. Science 2009; 325(5943): 10011005

15. Oestreich KJ, Read KA, Gilbertson SE, Hough KP, McDonald PW, Krishnamoorthy V, Weinmann AS. Bcl-6 directly represses the gene program of the glycolysis pathway. Nat Immunol 2014; 15(10): 957-964

16. Oestreich KJ, Mohn SE, Weinmann AS. Molecular mechanisms that control the expression and activity of Bcl-6 in TH1 cells to regulate flexibility with a TFH-like gene profile. Nat Immunol 2012; 13(4): 405-411

17. Scharping NE, Menk AV, Moreci RS, Whetstone RD, Dadey RE, Watkins SC, Ferris RL, Delgoffe GM. The tumor microenvironment represses $\mathrm{T}$ cell mitochondrial biogenesis to drive intratumoral $\mathrm{T}$ cell metabolic insufficiency and dysfunction. Immunity 2016; 45(3): 701-703

18. Bengsch B, Johnson AL, Kurachi M, Odorizzi PM, Pauken KE, Attanasio J, Stelekati E, McLane LM, Paley MA, Delgoffe GM, Wherry EJ. Bioenergetic insufficiencies due to metabolic alterations regulated by the inhibitory receptor PD-1 are an early driver of $\mathrm{CD}^{+} \mathrm{T}$ cell exhaustion. Immunity 2016; 45(2): 358-373

19. Austin S, St-Pierre J. PGC1 $\alpha$ and mitochondrial metabolism-emerging concepts and relevance in ageing and neurodegenerative disorders. J Cell Sci 2012; 125(Pt 21): 4963-4971

20. Siska PJ, van der Windt GJ, Kishton RJ, Cohen S, Eisner W, MacIver NJ, Kater AP, Weinberg JB, Rathmell JC. Suppression of Glut1 and glucose metabolism by decreased Akt/mTORC1 signaling drives T cell impairment in B cell leukemia. J Immunol 2016; 197(6): 2532-2540

21. Fox CJ, Hammerman PS, Thompson CB. Fuel feeds function: energy metabolism and the T-cell response. Nat Rev Immunol 2005; 5(11): 844-852

22. Vander Heiden MG, Cantley LC, Thompson CB. Understanding the Warburg effect: the metabolic requirements of cell proliferation. Science 2009; 324(5930): 1029-1033

23. Wahl DR, Byersdorfer CA, Ferrara JL, Opipari AW Jr, Glick GD. Distinct metabolic programs in activated T cells: opportunities for selective immunomodulation. Immunol Rev 2012; 249(1): 104-115

24. De Boer RJ, Homann D, Perelson AS. Different dynamics of CD4 ${ }^{+}$ and $\mathrm{CD} 8^{+} \mathrm{T}$ cell responses during and after acute lymphocytic choriomeningitis virus infection. J Immunol 2003; 171(8): 39283935

25. Pearce EL, Walsh MC, Cejas PJ, Harms GM, Shen H, Wang LS, Jones RG, Choi Y. Enhancing CD8 T-cell memory by modulating fatty acid metabolism. Nature 2009; 460(7251): 103-107

26. Schwenk RW, Holloway GP, Luiken JJ, Bonen A, Glatz JF. Fatty acid transport across the cell membrane: regulation by fatty acid transporters. Prostaglandins Leukot Essent Fatty Acids 2010; 82(46): 149-154

27. Michalek RD, Gerriets VA, Jacobs SR, Macintyre AN, MacIver NJ, Mason EF, Sullivan SA, Nichols AG, Rathmell JC. Cutting edge: distinct glycolytic and lipid oxidative metabolic programs are essential for effector and regulatory $\mathrm{CD}^{+}{ }^{+} \mathrm{T}$ cell subsets. J Immunol 
2011; 186(6): 3299-3303

28. Delgoffe GM, Pollizzi KN, Waickman AT, Heikamp E, Meyers DJ, Horton MR, Xiao B, Worley PF, Powell JD. The kinase mTOR regulates the differentiation of helper $\mathrm{T}$ cells through the selective activation of signaling by mTORC1 and mTORC2. Nat Immunol 2011; 12(4): 295-303

29. van der Windt GJ, Everts B, Chang CH, Curtis JD, Freitas TC, Amiel E, Pearce EJ, Pearce EL. Mitochondrial respiratory capacity is a critical regulator of $\mathrm{CD} 8^{+} \mathrm{T}$ cell memory development. Immunity 2012; 36(1): 68-78

30. Lochner M, Berod L, Sparwasser T. Fatty acid metabolism in the regulation of $\mathrm{T}$ cell function. Trends Immunol 2015; 36(2): 81-91

31. Fraser KA, Schenkel JM, Jameson SC, Vezys V, Masopust D. Preexisting high frequencies of memory $\mathrm{CD}^{+} \mathrm{T}$ cells favor rapid memory differentiation and preservation of proliferative potential upon boosting. Immunity 2013; 39(1): 171-183

32. van der Windt GJ, O'Sullivan D, Everts B, Huang SC, Buck MD, Curtis JD, Chang CH, Smith AM, Ai T, Faubert B, Jones RG, Pearce EJ, Pearce EL. CD8 memory T cells have a bioenergetic advantage that underlies their rapid recall ability. Proc Natl Acad Sci USA 2013; 110(35): 14336-14341

33. Nicholls DG. Spare respiratory capacity, oxidative stress and excitotoxicity. Biochem Soc Trans 2009; 37(Pt 6): 1385-1388

34. Newsholme EA, Crabtree B, Ardawi MS. The role of high rates of glycolysis and glutamine utilization in rapidly dividing cells. Biosci Rep 1985; 5(5): 393-400

35. van Stipdonk MJ, Hardenberg G, Bijker MS, Lemmens EE, Droin NM, Green DR, Schoenberger SP. Dynamic programming of CD8 ${ }^{+}$ T lymphocyte responses. Nat Immunol 2003; 4(4): 361-365

36. Rathmell JC, Vander Heiden MG, Harris MH, Frauwirth KA, Thompson CB. In the absence of extrinsic signals, nutrient utilization by lymphocytes is insufficient to maintain either cell size or viability. Mol Cell 2000; 6(3): 683-692

37. Mueckler M, Thorens B. The SLC2 (GLUT) family of membrane transporters. Mol Aspects Med 2013; 34(2-3): 121-138

38. Scheepers A, Joost HG, Schürmann A. The glucose transporter families SGLT and GLUT: molecular basis of normal and aberrant function. JPEN J Parenter Enteral Nutr 2004; 28(5): 364-371

39. Wood IS, Trayhurn P. Glucose transporters (GLUT and SGLT): expanded families of sugar transport proteins. Br J Nutr 2003; 89(1): 3-9

40. Macintyre AN, Gerriets VA, Nichols AG, Michalek RD, Rudolph MC, Deoliveira D, Anderson SM, Abel ED, Chen BJ, Hale LP, Rathmell JC. The glucose transporter Glutl is selectively essential for CD4 T cell activation and effector function. Cell Metab 2014; 20 (1): 61-72

41. Qu Q, Zeng F, Liu X, Wang QJ, Deng F. Fatty acid oxidation and carnitine palmitoyltransferase I: emerging therapeutic targets in cancer. Cell Death Dis 2016; 7(5): e2226

42. Chakrabarti R, Jung CY, Lee TP, Liu H, Mookerjee BK. Changes in glucose transport and transporter isoforms during the activation of human peripheral blood lymphocytes by phytohemagglutinin. J Immunol 1994; 152(6): 2660-2668

43. Frauwirth KA, Riley JL, Harris MH, Parry RV, Rathmell JC, Plas DR, Elstrom RL, June CH, Thompson CB. The CD28 signaling pathway regulates glucose metabolism. Immunity 2002; 16(6): 769777
44. Jacobs SR, Herman CE, Maciver NJ, Wofford JA, Wieman HL, Hammen JJ, Rathmell JC. Glucose uptake is limiting in T cell activation and requires CD28-mediated Akt-dependent and independent pathways. J Immunol 2008; 180(7): 4476-4486

45. Nakaya M, Xiao Y, Zhou X, Chang JH, Chang M, Cheng X, Blonska M, Lin X, Sun SC. Inflammatory T cell responses rely on amino acid transporter ASCT2 facilitation of glutamine uptake and mTORC1 kinase activation. Immunity 2014; 40(5): 692-705

46. Sinclair LV, Rolf J, Emslie E, Shi YB, Taylor PM, Cantrell DA. Control of amino-acid transport by antigen receptors coordinates the metabolic reprogramming essential for $\mathrm{T}$ cell differentiation. Nat Immunol 2013; 14(5): 500-508

47. Verrey F, Closs EI, Wagner CA, Palacin M, Endou H, Kanai Y. CATs and HATs: the SLC7 family of amino acid transporters. Pflugers Arch 2004; 447(5): 532-542

48. Hayashi K, Jutabha P, Endou H, Sagara H, Anzai N. LAT1 is a critical transporter of essential amino acids for immune reactions in activated human T cells. J Immunol 2013; 191(8): 4080-4085

49. Pearce EL, Walsh MC, Cejas PJ, Harms GM, Shen H, Wang LS, Jones RG, Choi Y. Enhancing CD8 T-cell memory by modulating fatty acid metabolism. Nature 2009; 460(7251): 103-107

50. Rao RR, Li Q, Odunsi K, Shrikant PA. The mTOR kinase determines effector versus memory $\mathrm{CD}^{+} \mathrm{T}$ cell fate by regulating the expression of transcription factors T-bet and Eomesodermin. Immunity 2010; 32(1): 67-78

51. Araki K, Turner AP, Shaffer VO, Gangappa S, Keller SA, Bachmann MF, Larsen CP, Ahmed R. mTOR regulates memory CD8 T-cell differentiation. Nature 2009; 460(7251): 108-112

52. Brown EJ, Albers MW, Shin TB, Ichikawa K, Keith CT, Lane WS, Schreiber SL. A mammalian protein targeted by G1-arresting rapamycin-receptor complex. Nature 1994; 369(6483): 756-758

53. Delgoffe GM, Kole TP, Zheng Y, Zarek PE, Matthews KL, Xiao B, Worley PF, Kozma SC, Powell JD. The mTOR kinase differentially regulates effector and regulatory $\mathrm{T}$ cell lineage commitment. Immunity 2009; 30(6): 832-844

54. Battaglia M, Stabilini A, Migliavacca B, Horejs-Hoeck J, Kaupper $\mathrm{T}$, Roncarolo MG. Rapamycin promotes expansion of functional $\mathrm{CD} 4{ }^{+} \mathrm{CD} 25^{+} \mathrm{FOXP}^{+}{ }^{+}$regulatory $\mathrm{T}$ cells of both healthy subjects and type 1 diabetic patients. J Immunol 2006; 177(12): 8338-8347

55. Battaglia M, Stabilini A, Roncarolo MG. Rapamycin selectively expands $\mathrm{CD}^{+}{ }^{+} \mathrm{CD} 25^{+} \mathrm{FoxP}^{+}$regulatory T cells. Blood 2005; 105 (12): 4743-4748

56. Kurebayashi Y, Nagai S, Ikejiri A, Ohtani M, Ichiyama K, Baba Y, Yamada T, Egami S, Hoshii T, Hirao A, Matsuda S, Koyasu S. PI3K-Akt-mTORC1-S6K1/2 axis controls Th17 differentiation by regulating Gfil expression and nuclear translocation of ROR $\gamma$. Cell Reports 2012; 1(4): 360-373

57. Wu X, Dou Y, Yang Y, Bian D, Luo J, Tong B, Xia Y, Dai Y. Arctigenin exerts anti-colitis efficacy through inhibiting the differentiation of Th1 and Th17 cells via an mTORC1-dependent pathway. Biochem Pharmacol 2015; 96(4): 323-336

58. Yang K, Shrestha S, Zeng H, Karmaus PW, Neale G, Vogel P, Guertin DA, Lamb RF, Chi H. T cell exit from quiescence and differentiation into Th2 cells depend on Raptor-mTORC1-mediated metabolic reprogramming. Immunity 2013; 39(6): 1043-1056

59. Lee K, Gudapati P, Dragovic S, Spencer C, Joyce S, Killeen N, Magnuson MA, Boothby M. Mammalian target of rapamycin 
protein complex 2 regulates differentiation of Th1 and Th2 cell subsets via distinct signaling pathways. Immunity 2010; 32(6): 743753

60. Buller CL, Loberg RD, Fan MH, Zhu Q, Park JL, Vesely E, Inoki K, Guan KL, Brosius FC 3rd. A GSK-3/TSC2/mTOR pathway regulates glucose uptake and GLUT1 glucose transporter expression. Am J Physiol Cell Physiol 2008; 295(3): C836-C843

61. Gerriets VA, Kishton RJ, Nichols AG, Macintyre AN, Inoue M, Ilkayeva O, Winter PS, Liu X, Priyadharshini B, Slawinska ME, Haeberli L, Huck C, Turka LA, Wood KC, Hale LP, Smith PA, Schneider MA, MacIver NJ, Locasale JW, Newgard CB, Shinohara ML, Rathmell JC. Metabolic programming and PDHK1 control $\mathrm{CD}^{+}{ }^{+} \mathrm{T}$ cell subsets and inflammation. J Clin Invest 2015; 125(1): 194-207

62. Hadis U, Wahl B, Schulz O, Hardtke-Wolenski M, Schippers A, Wagner N, Müller W, Sparwasser T, Förster R, Pabst O. Intestinal tolerance requires gut homing and expansion of $\mathrm{FoxP} 3{ }^{+}$regulatory $\mathrm{T}$ cells in the lamina propria. Immunity 2011; 34(2): 237-246

63. Shi LZ, Wang R, Huang G, Vogel P, Neale G, Green DR, Chi H. HIF1 $\alpha$-dependent glycolytic pathway orchestrates a metabolic checkpoint for the differentiation of TH17 and Treg cells. J Exp Med 2011; 208(7): 1367-1376

64. Zeng H, Yang K, Cloer C, Neale G, Vogel P, Chi H. mTORC1 couples immune signals and metabolic programming to establish $\mathrm{T}$ (reg)-cell function. Nature 2013; 499(7459): 485-490

65. Hardie DG, Scott JW, Pan DA, Hudson ER. Management of cellular energy by the AMP-activated protein kinase system. FEBS Lett 2003; 546(1): 113-120

66. Hardie DG. Minireview: the AMP-activated protein kinase cascade: the key sensor of cellular energy status. Endocrinology 2003; 144 (12): 5179-5183

67. Tamás P, Hawley SA, Clarke RG, Mustard KJ, Green K, Hardie DG, Cantrell DA. Regulation of the energy sensor AMP-activated protein kinase by antigen receptor and $\mathrm{Ca}^{2+}$ in $\mathrm{T}$ lymphocytes. $\mathrm{J}$ Exp Med 2006; 203(7): 1665-1670

68. Xu J, Ji J, Yan XH. Cross-talk between AMPK and mTOR in regulating energy balance. Crit Rev Food Sci Nutr 2012; 52(5): 373-381

69. Zhao D, Long XD, Lu TF, Wang T, Zhang WW, Liu YX, Cui XL, Dai HJ, Xue F, Xia Q. Metformin decreases IL-22 secretion to suppress tumor growth in an orthotopic mouse model of hepatocellular carcinoma. Int J Cancer 2015; 136(11): 25562565

70. Kang KY, Kim YK, Yi H, Kim J, Jung HR, Kim IJ, Cho JH, Park $\mathrm{SH}$, Kim HY, Ju JH. Metformin downregulates Th17 cells differentiation and attenuates murine autoimmune arthritis. Int Immunopharmacol 2013; 16(1): 85-92

71. Bai A, Yong M, Ma AG, Ma Y, Weiss CR, Guan Q, Bernstein CN, Peng Z. Novel anti-inflammatory action of 5-aminoimidazole-4carboxamide ribonucleoside with protective effect in dextran sulfate sodium-induced acute and chronic colitis. J Pharmacol Exp Ther 2010; 333(3): 717-725

72. Son HJ, Lee J, Lee SY, Kim EK, Park MJ, Kim KW, Park SH, Cho ML. Metformin attenuates experimental autoimmune arthritis through reciprocal regulation of Th17/Treg balance and osteoclastogenesis. Mediators Inflamm 2014; 2014: 973986

73. Lee SY, Lee SH, Yang EJ, Kim EK, Kim JK, Shin DY, Cho ML.
Metformin ameliorates inflammatory bowel disease by suppression of the STAT3 signaling pathway and regulation of the between Th17/Treg balance. PLoS One 2015; 10(9): e0135858

74. Bai A, Ma AG, Yong M, Weiss CR, Ma Y, Guan Q, Bernstein CN, Peng $Z$. AMPK agonist downregulates innate and adaptive immune responses in TNBS-induced murine acute and relapsing colitis. Biochem Pharmacol 2010; 80(11): 1708-1717

75. Nath N, Giri S, Prasad R, Salem ML, Singh AK, Singh I. 5aminoimidazole-4-carboxamide ribonucleoside: a novel immunomodulator with therapeutic efficacy in experimental autoimmune encephalomyelitis. J Immunol 2005; 175(1): 566-574

76. Boxer LM, Dang CV. Translocations involving c-myc and c-myc function. Oncogene 2001; 20(40): 5595-5610

77. Erikson J, ar-Rushdi A, Drwinga HL, Nowell PC, Croce CM. Transcriptional activation of the translocated c-myc oncogene in burkitt lymphoma. Proc Natl Acad Sci USA 1983; 80(3): 820-824

78. Wang R, Dillon CP, Shi LZ, Milasta S, Carter R, Finkelstein D, McCormick LL, Fitzgerald P, Chi H, Munger J, Green DR. The transcription factor Myc controls metabolic reprogramming upon $\mathrm{T}$ lymphocyte activation. Immunity 2011; 35(6): 871-882

79. Sinclair LV, Rolf J, Emslie E, Shi YB, Taylor PM, Cantrell DA. Control of amino-acid transport by antigen receptors coordinates the metabolic reprogramming essential for $\mathrm{T}$ cell differentiation. Nat Immunol 2013; 14(5): 500-508

80. Molon B, Calì B, Viola A. T cells and cancer: how metabolism shapes immunity. Front Immunol 2016; 7: 20

81. Frey AB. Suppression of $\mathrm{T}$ cell responses in the tumor microenvironment. Vaccine 2015; 33(51): 7393-7400

82. Vinay DS, Ryan EP, Pawelec G, Talib WH, Stagg J, Elkord E, Lichtor T, Decker WK, Whelan RL, Kumara HMCS, Signori E, Honoki K, Georgakilas AG, Amin A, Helferich WG, Boosani CS, Guha G, Ciriolo MR, Chen S, Mohammed SI, Azmi AS, Keith WN, Bilsland A, Bhakta D, Halicka D, Fujii H, Aquilano K, Ashraf SS, Nowsheen S, Yang X, Choi BK, Kwon BS. Immune evasion in cancer: mechanistic basis and therapeutic strategies. Semin Cancer Biol 2015; 35(Suppl): S185-S198

83. Kim R, Emi M, Tanabe K. Cancer immunoediting from immune surveillance to immune escape. Immunology 2007; 121(1): 1-14

84. Gajewski TF, Fuertes M, Spaapen R, Zheng Y, Kline J. Molecular profiling to identify relevant immune resistance mechanisms in the tumor microenvironment. Curr Opin Immunol 2011; 23(2): 286292

85. Bianchi G, Borgonovo G, Pistoia V, Raffaghello L. Immunosuppressive cells and tumour microenvironment: focus on mesenchymal stem cells and myeloid derived suppressor cells. Histol Histopathol 2011; 26(7): 941-951

86. Taylor ES, McCall JL, Girardin A, Munro FM, Black MA, Kemp RA. Functional impairment of infiltrating $\mathrm{T}$ cells in human colorectal cancer. OncoImmunology 2016; 5(11): e1234573

87. Quail DF, Joyce JA. Microenvironmental regulation of tumor progression and metastasis. Nat Med 2013; 19(11): 1423-1437

88. Herbel C, Patsoukis N, Bardhan K, Seth P, Weaver JD, Boussiotis VA. Clinical significance of $\mathrm{T}$ cell metabolic reprogramming in cancer. Clin Transl Med 2016; 5(1): 29

89. Chang CH, Qiu J, O'Sullivan D, Buck MD, Noguchi T, Curtis JD, Chen Q, Gindin M, Gubin MM, van der Windt GJ, Tonc E, Schreiber RD, Pearce EJ, Pearce EL. Metabolic competition in the 
tumor microenvironment is a driver of cancer progression. Cell 2015; 162(6): 1229-1241

90. Zhang Y, Ertl HC. Starved and asphyxiated: how can $\mathrm{CD} 8^{+} \mathrm{T}$ cells within a tumor microenvironment prevent tumor progression. Front Immunol 2016; 7: 32

91. Nakaigawa N, Kondo K, Ueno D, Namura K, Makiyama K, Kobayashi K, Shioi K, Ikeda I, Kishida T, Kaneta T, Minamimoto $\mathrm{R}$, Tateishi $\mathrm{U}$, Inoue $\mathrm{T}$, Yao $\mathrm{M}$. The acceleration of glucose accumulation in renal cell carcinoma assessed by FDG PET/CT demonstrated acquisition of resistance to tyrosine kinase inhibitor therapy. BMC Cancer 2017; 17(1): 39

92. Crespo J, Sun H, Welling TH, Tian Z, Zou W. T cell anergy, exhaustion, senescence, and stemness in the tumor microenvironment. Curr Opin Immunol 2013; 25(2): 214-221

93. Chaudhary B, Elkord E. Regulatory $\mathrm{T}$ cells in the tumor microenvironment and cancer progression: role and therapeutic targeting. Vaccines (Basel) 2016; 4(3): E28

94. Yaqub S, Henjum K, Mahic M, Jahnsen FL, Aandahl EM, Bjørnbeth BA, Taskén K. Regulatory $\mathrm{T}$ cells in colorectal cancer patients suppress anti-tumor immune activity in a COX-2 dependent manner. Cancer Immunol Immunother 2008; 57(6): 813-821

95. Chaudhary B, Abd Al Samid M, al-Ramadi BK, Elkord E. Phenotypic alterations, clinical impact and therapeutic potential of regulatory T cells in cancer. Expert Opin Biol Ther 2014; 14(7): 931-945

96. Chi $\mathrm{H}$. Regulation and function of mTOR signalling in $\mathrm{T}$ cell fate decisions. Nat Rev Immunol 2012; 12(5): 325-338

97. Chaube B, Bhat MK. AMPK, a key regulator of metabolic/energy homeostasis and mitochondrial biogenesis in cancer cells. Cell Death Dis 2016; 7(1): e2044 